\title{
Modelling Soil Water Retention for Weed Seed Germination Sensitivity to Water Potential
}

\author{
W. John Bullied, ${ }^{1}$ Paul R. Bullock, ${ }^{2}$ and Rene C. Van Acker ${ }^{1}$ \\ ${ }^{1}$ Department of Plant Agriculture, University of Guelph, Guelph, ON, Canada N1G 2W1 \\ ${ }^{2}$ Department of Soil Science, University of Manitoba, Winnipeg, MB, Canada R3T 2N2
}

Correspondence should be addressed to W. John Bullied, john.bullied@uoguelph.ca

Received 14 October 2011; Accepted 31 January 2012

Academic Editor: Keith Smettem

Copyright ( 92012 W. John Bullied et al. This is an open access article distributed under the Creative Commons Attribution License, which permits unrestricted use, distribution, and reproduction in any medium, provided the original work is properly cited.

\begin{abstract}
Soil water retention is important for the study of water availability to germinating weed seeds. Six soil water retention models (Campbell, Brooks-Corey, four- and five-parameter van Genuchten, Tani, and Russo) with residual soil water parameter derivations were evaluated to describe water retention for weed seed germination at minimum threshold soil water potential for three hillslope positions. The Campbell, Brooks-Corey, and four-parameter van Genuchten model with modified or estimated forms of the residual parameter had superior but similar data fit. The Campbell model underestimated water retention at a potential less than $-0.5 \mathrm{MPa}$ for the upper hillslope that could result in underestimating seed germination. The Tani and Russo models overestimated water retention at a potential less than $-0.1 \mathrm{MPa}$ for all hillslope positions. Model selection and residual parameter specification are important for weed seed germination by representing water retention at the level of minimum threshold water potential for germination. Weed seed germination models driven by the hydrothermal soil environment rely on the best-fitting soil water retention model to produce dynamic predictions of seed germination.
\end{abstract}

\section{Introduction}

The soil water retention characteristic (SWRC) is a basic hydrophysical property of the soil that relates the water content of soil water to its energy state [1]. The water content-potential function $\theta(\psi)$ is fundamental to the characterization of water holding capacity, water retention, and water flow in soil $[2,3]$. The SWRC is necessary for modelling fluxes in soil water and is needed for germination studies where soil water is measured on a content basis.

The timing of seed germination is a function of soil water potential [4]. As the soil dries, soil water potential is reduced, and it becomes increasingly difficult for seeds to imbibe water. At the minimum threshold (base) water potential, seeds do not imbibe sufficient water to initiate embryo growth and complete the germination process. The minimum threshold water potential at which germination ceases to occur in many agricultural weeds ranges from -0.1 to $-1.5 \mathrm{MPa}[5,6]$. Accurate representation of the SWRC over a wide range of water potential minimum thresholds is required for predictive modelling of seed germination.

One of the greatest challenges in characterizing the SWRC for the shallow depth of the seedling recruitment zone (soil layer from which seeds germinate and emerge) across field topography is obtaining the parameters of the soil hydrological property. Determining the SWRC by direct measurement is time-consuming to obtain sufficient representation of a field due to spatial variability of soil properties $[7,8]$. The ability of the soil to retain and transmit water is specific to soil type, and is affected by texture, pore-size and pore arrangement [1].

Diverse SWRC often exist in soils along a hillslope as a result of variability in texture and pore-size distribution $[9,10]$. Soil physical properties have been shown to reflect hillslope position with much greater variability between positions than within a position $[11,12]$. Soil topographical variability in texture is related to differences between hillslope positions [13]. 
The SWRC is expressed as a nonlinear function in which water content decreases from saturation to dryness in a sigmoidal manner with decreasing (more negative) water potential $[14,15]$. Predicting $\theta(\psi)$ is particularly important for the minimum threshold water potential for seed germination within the range of soil water potential of -0.1 to $-1.5 \mathrm{MPa}$. Anchoring the residual water content $\left(\theta_{r}\right)$ may represent the dry end of the soil water potential range to specify the point at which seed germination ceases to occur. The residual soil water content is the water content at the dry end of the SWRC at which the gradient $d \theta / d \psi$ becomes zero and unsaturated hydraulic conductivity ceases [15]. Furthermore, some SWRC models represent $d \theta / d \psi$ near the wet end of the range of soil water as a continuous function, whereas other SWRC models represent $d \theta / d \psi$ as discontinuous. The objectives of this study were to (1) compare SWRC models to determine the best-fitting model for the measured soil water data across categorical hillslope positions (summit, backslope, and toeslope) and (2) to evaluate the SWRC models to describe weed seed germination sensitivity to soil water potential within specified water potential intervals for the shallow seedling recruitment zone at the categorical hillslope positions.

\section{Materials and Methods}

2.1. Experimental Site. The SWRC in the shallow seedling recruitment zone was evaluated in three hillslope positions (summit, backslope, and toeslope) on two hillslopes having opposing aspects in an annually cropped agricultural field at Graysville, MB, Canada. Each hillslope contained six replications that were arranged perpendicular to the hillslope gradient to maximize homogeneous soil conditions at each hillslope position.

2.2. Soil Physical Properties. Soil samples were extracted from the $25-50 \mathrm{~mm}$ soil depth in three replicates by pressing $50 \mathrm{~mm}$ diameter by $25 \mathrm{~mm}$ deep rings into the soil. The $25-$ $50 \mathrm{~mm}$ soil depth is representative of average weed seedling recruitment depth in a conventionally tilled field [16]. Furthermore, the $25-50 \mathrm{~mm}$ soil depth has been shown to have optimal hydrothermal properties for seed germination over a wide range of minimum threshold water potentials compared to shallower or deeper soil depths [17]. The 25$50 \mathrm{~mm}$ soil depth was also selected for analysis as part of a larger study on the soil water retention characteristics of the seedling recruitment zone [18].

Subsamples of soil weighing $12 \mathrm{~g}$ were placed in shallow Plexiglas cylinders and saturated for $24 \mathrm{~h}$. Volumetric water content at saturation was determined by placing the soil samples on saturated porous plates in covered ceramic suction cups to equilibrate saturation water content over $48 \mathrm{~h}$. Volumetric water content was determined on desaturation at pressures of $0.01,0.03,0.05$, and $0.1 \mathrm{MPa}$ with a model 1600 0.5-MPa pressure plate extractor with a 0.1-MPa porous ceramic pressure plate and determined at pressures of 0.5 and 1.5 MPa with a model 15001.5 -MPa pressure plate extractor with $0.5-\mathrm{MPa}$ and $1.5-\mathrm{MPa}$ porous ceramic pressure plates
(Soil Moisture Equipment Corp., Santa Barbara, CA, USA) according to methods by [19]. At each pressure equilibrium, soils were removed from the ceramic plates and oven-dried at $105^{\circ} \mathrm{C}$ for $48 \mathrm{~h}$.

Soil particle size was analysed by the hydrometer method [20]. Organic matter content (OM) was determined by the loss on ignition procedure [21]. Bulk density (BD) was determined by averaging gravimetric soil water samples of a known volume in six replications from each hillslope position. Soil physical properties were analysed with the mixed procedure using statistical analysis systems (SAS) [22]. Mean separation of soil physical properties was analysed across all hillslope positions using Fisher's protected LSD.

2.3. Soil Water Retention Models. Commonly used SWRC equations having a low number of parameters were evaluated for their ability to fit the data. The Brooks-Corey (BC) model [14] is a four-parameter equation in which water content is expressed as a power function of soil water pressure using the expression:

$$
\theta= \begin{cases}\theta_{r}+\left(\theta_{s}-\theta_{r}\right)\left[\frac{\psi}{\psi_{e}}\right]^{-\lambda} & \text { for } \psi<\psi_{e} \\ \theta_{s} & \text { for } \psi \geq \psi_{e}\end{cases}
$$

where $\theta$ is volumetric water content, $\psi$ is matric potential, $\theta_{s}$ is saturated volumetric water content, $\theta_{r}$ is residual soil water content when $\psi$ is infinitely small, $\psi_{e}$ is a curve-fitting parameter, known as the air entry matric suction, and $\lambda$ is a pore-size distribution factor. The restriction $\theta=\theta_{s}$ is applied for $\psi \geq \psi_{e}$ to prevent overestimation of water content at low matric suctions. The Campbell (CA) model [23] is a threeparameter power function to obtain water content from soil water potential:

$$
\theta= \begin{cases}\theta_{s}\left[\frac{\psi}{\psi_{e}}\right]^{\lambda} & \text { for } \psi<\psi_{e} \\ \theta=\theta_{s} & \text { for } \psi \geq \psi_{e}\end{cases}
$$

where $\psi_{e}$ is the air entry matric suction, and $\lambda$ is a curvefitting parameter representing pore-size distribution where $\lambda=-1 / \beta$, and $\beta$ is an empirically derived constant. The Campbell equation is similar to the Brooks-Corey model but with $\theta_{r}=0$. The van Genuchten $\left(\mathrm{VG}_{5}\right)$ model [15] is an expression originally based on five parameters:

$$
\theta=\theta_{r}+\left(\theta_{s}-\theta_{r}\right)\left[1+(\alpha \psi)^{n}\right]^{-m}
$$

where $\alpha$ is a curve-fitting parameter related to $\psi^{-1}$ and the slope of the curve at inflection, and $n$ and $m$ are dimensionless curve-fitting parameters. The parameters are contingent on the pore-size distribution. The four-parameter van Genuchten $\left(\mathrm{VG}_{4}\right)$ model is similar to the $\mathrm{VG}_{5}$ model 
except for $m=1-1 / n$ [15]. The Tani (TA) model [24] is a three-parameter model using the expression:

$$
\theta=\theta_{r}+\left(\theta_{s}-\theta_{r}\right)\left[1+\frac{\psi}{\psi_{o}}\right] \exp \left(-\frac{\psi}{\psi_{o}}\right)
$$

where $\psi_{o}$ is the soil water potential at the inflection point on the curve. The Russo (RU) model [25] is a four-parameter model that produces the water conductivity-capillary potential relationship when integrated into Mualem's model [26] model for relative hydraulic conductivity:

$$
\theta=\theta_{r}+\left(\theta_{s}-\theta_{r}\right)[(1+0.5 \alpha|\psi|) \exp (-0.5 \alpha|\psi|)]^{2 /(m+2)},
$$

where $\alpha$ is related to the width of the pore-size distribution and is interpreted as the inverse of the air entry matric suction, and $m$ accounts for the dependence of the tortuosity and the correlation factors on the soil water content.

2.4. Soil Water Retention Model Evaluation. The fitted SWRC for the $25-50 \mathrm{~mm}$ soil depth of the hillslope positions was determined by nonlinear analysis with the likelihoodbased NLMIXED procedure using iterative optimization to compute the parameter estimates [22]. The values for $\theta_{s}$ were taken from measurements at saturation. Three derivations of $\theta_{r}$ were explored to determine the influence of $\theta_{r}$ on the dry range of the SWRC, since the minimum threshold water potential for seed germination of most weed species is within the dry range of water potential values (from -0.1 to $-1.5 \mathrm{MPa}$ ). Values of $\theta_{r}$ derived from measurements at $-1.5 \mathrm{MPa}$ (the permanent wilting point) were designated $\theta_{r(W)}$. For practical purposes, $\theta_{r}$ can sufficiently be defined as the water content at a large negative value such as the permanent wilting point, despite further desorption of water with increasing suction [15]. The second derivation of $\theta_{r}$ was modified by a logarithmic equation describing the adsorption of water on soil in the dry range of the retention curve $[27,28]$ :

$$
\theta=\left[1-\frac{\ln (\psi)}{\ln \left(\psi_{m}\right)}\right] \theta_{a}
$$

where $\theta_{a}$ is a curve-fitting parameter representing the volumetric water content when $\psi=1$, and $\psi_{m}$ is the matric suction at oven dryness, which is generally accepted to be $10^{3} \mathrm{MPa}$. The modified form of $\theta_{r}$ is assigned $\theta_{r(M)}$. The third derivation of $\theta_{r}$ was estimated as one of the fitted parameters, referred to $\theta_{r(E)}$, which contained the restriction $\theta_{r} \geq 0$. In all cases, the optimization results were improved by setting the measured value of $\theta_{s}$ as a constant parameter. Previous SWRC estimates have shown improvement by using known constant rather than optimized values of $\theta_{s}$ [29]. The $\mathrm{BC}$ and CA models were analysed as discontinuous $d \theta / d \psi$ models, whereas the VG, TA, and RU models were analysed as continuous $d \theta / d \psi$ models.

The Akaike information criterion (AIC) [30] was used to evaluate the SWRC models. The AIC selected for the most parsimonious model $[31,32]$. The AIC is a likelihood-based comparison of the data for model discrimination expressed as:

$$
\mathrm{AIC}=-2 \log (\text { likelihood })+2 k,
$$

where $k$ is the number of estimable model parameters. The AIC selects for a model that fits well and has a low number of parameters. The AIC compares the data to a probability index, with a lower value of AIC indicating a better fitting model. The AIC is a relative ranking statistic; therefore, values are interpreted in terms of the magnitude of their differences among all models being considered.

Model comparisons were facilitated using delta $\operatorname{AIC}\left(\Delta_{i}\right)$ and Akaike weights $\left(w_{i}\right)[31,33]$. Delta AIC is a measure of the AIC differences of each model relative to the best model derived by:

$$
\Delta_{i}=\mathrm{AIC}_{i}-\mathrm{AIC}_{\min },
$$

where $\mathrm{AIC}_{i}$ is the $\mathrm{AIC}$ value for model $i$, and $\mathrm{AIC}_{\min }$ is the smallest value of AIC in the set of candidate models. The relative likelihood of each SWRC model was realized by relative scaling of the models with $w_{i}$ [31]. Akaike weights provide an effective way to scale and interpret the $\Delta_{i}$ values by comparing the ratio of each model to the best model relative to the entire set of candidate models by:

$$
w_{i}=\frac{\exp \left(-\Delta_{i} / 2\right)}{\sum_{r=1}^{R} \exp \left(-\Delta_{r} / 2\right)},
$$

given a set of $R$ models being evaluated. Akaike weights compare models on a scale of one (the sum of $w_{i}$ equals one) indicating the weight of evidence that model $i$ is superior among the set of $R$ models [31].

Model inference was based on evidence ratios that evaluate the relative likelihood of model pairs. Evidence ratios are calculated as the ratio of Akaike weights $\left(w_{i} / w_{j}\right)$, where $i$ is the estimated best model in the set, and $j$ indexes the remaining models in the set. Evidence ratios provide support for the fitted models as to which one is superior, by comparing models in a pairwise approach that is invariant to all models in the set except the $i$ and $j$ models [31].

2.5. Weed Seed Germination Sensitivity to Soil Water Potential. The best-fitting curve according to Akaike weights from the $\theta_{r}$ derivations for each SWRC model was retained to explore differences in weed seed germination sensitivity to soil water potential across the hillslope positions. The range of measured water potential values $(-0.01$ to $-1.5 \mathrm{MPa})$ was divided into four intervals (A: -0.01 to $-0.1 \mathrm{MPa}$; $\mathrm{B}$ : -0.1 to $-0.5 \mathrm{MPa}$; $\mathrm{C}:-0.5$ to $-1.0 \mathrm{MPa}$; $\mathrm{D}:-1.0$ to $-1.5 \mathrm{MPa}$ ) to represent groups of minimum threshold water potential for germination. The mean water content for the full range of measured water potential values and water potential intervals was calculated by numerical quadrature with the following integral using the average value of a function [34]:

$$
\bar{\theta}=\frac{1}{b-a} \int_{a}^{b} \theta_{m} d \log \psi,
$$

where $\bar{\theta}$ is the mean water content $\left(\mathrm{cm}^{3} / \mathrm{cm}^{3}\right)$, and $\theta_{m}$ is the SWRC fitted to the measured water contents $\left(\mathrm{cm}^{3} / \mathrm{cm}^{3}\right)$. The 


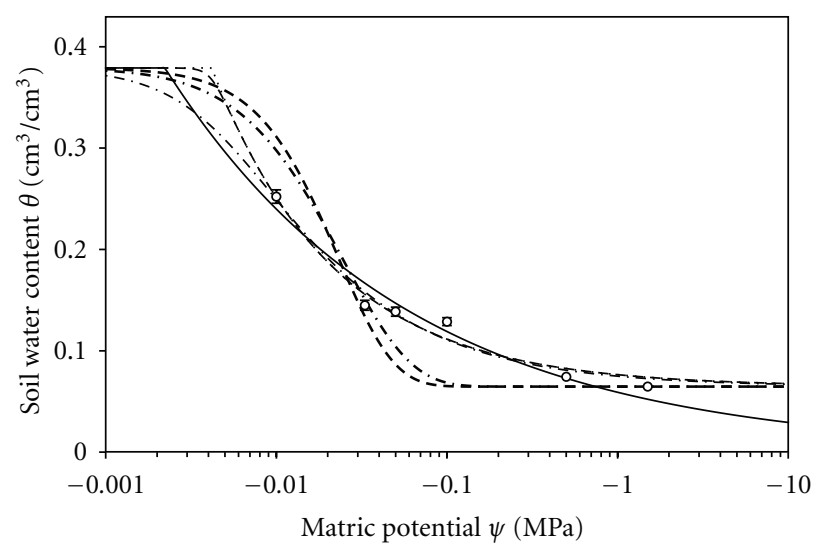

(a) Summit

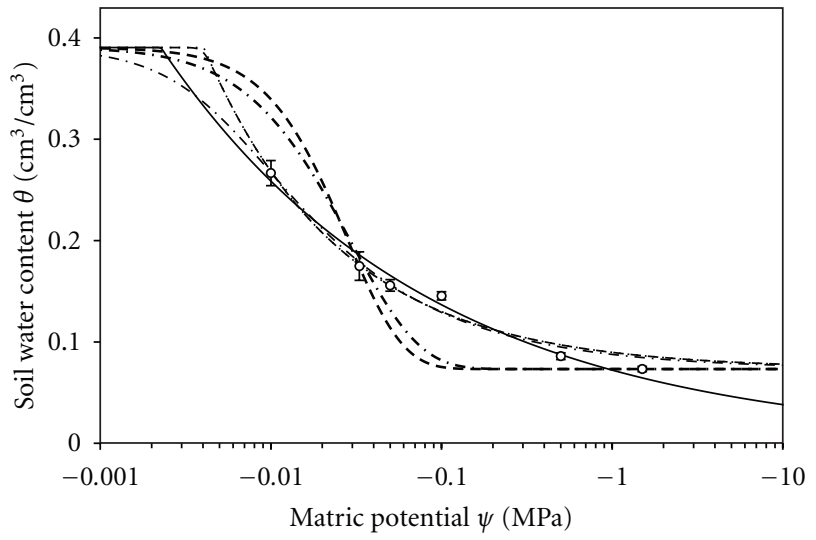

(b) Backslope

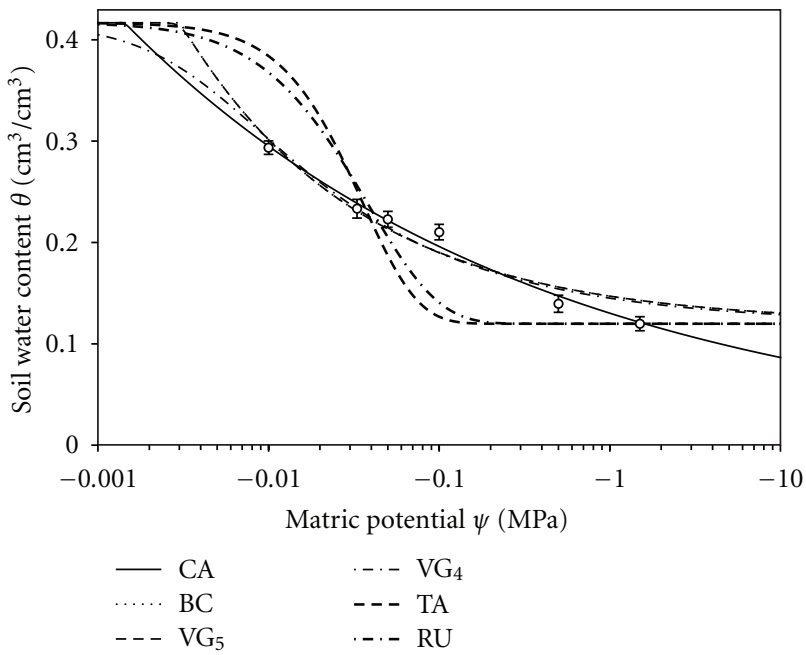

(c) Toeslope

FIGURE 1: Fitted SWRC for soil water contents $(\theta)$ at soil matric potentials $(\psi)$ for the (a) summit, (b) backslope, and (c) toeslope positions averaged across two hillslopes using the Campbell (CA) model with absent $\theta_{r}$ parameter, and Brooks-Corey (BC), five- and four-parameter van Genuchten $\left(\mathrm{VG}_{5}\right.$ and $\mathrm{VG}_{4}$ ), Tani (TA), and Russo (RU) models with $\theta_{r}$ constrained to measured values at $-1.5 \mathrm{MPa}$. Error bars are SE for six water retention measurements.

integration boundaries $a$ and $b$ define the integration interval over which the mean water content was derived. The lognormal distribution of $\psi$ was calculated using $\log _{10} \psi$ to avoid overweighting of the dry end of the SWRC.

Mean water contents for the best-fitting $\theta_{r}$ derivation of each SWRC model were compared across hillslope positions by mean separation with Fisher's LSD using mixed model analysis. Hillslopes were combined, and hillslope position by SWRC model interactive effect was explored. Mean water content of each SWRC model was compared to that of the best-fitting model.

\section{Results and Discussion}

3.1. Soil Physical Properties. The hillslope positions (summit, backslope, and toeslope) represented a categorical range in soil physical properties along the hillslope. Surface soil texture ranged from loamy fine sand to silty clay (Table 1). Greater clay content in the toeslope was likely due to sorting of soil particles by hydrologic processes that would, over time, result in smaller soil particles, predominantly clay, to accumulate downslope [35]. Greater OM levels in the toeslope positions could be attributed to downhill transport and accumulation of OM. Bulk density did not vary greatly across the hillslope positions probably as a result of rotary tillage used for the accompanying experiment. The exception to relatively homogeneous $\mathrm{BD}$ among the hillslope positions was the SW toeslope which had higher OM that contributed to lower BD measured at that position.

3.2. Soil Water Retention Model Evaluation. The respective SWRC models (excluding CA) all exhibited better fit with modified $\left(\theta_{r(M)}\right)$ or estimated $\left(\theta_{r(E)}\right)$ forms of $\theta_{r}$ over that of measured $\left(\theta_{r(W)}\right)$ as indicated by lower values of AIC (Table 2). This may be an indication that modified or estimated forms of $\theta_{r}$ were better represented by values other than those measured at $-1.5 \mathrm{MPa}$. Estimating or modifying 
TABLE 1: Average measured soil physical properties for the shallow seedling recruitment zone of the hillslope positions.

\begin{tabular}{|c|c|c|c|c|c|c|}
\hline Hillslope position & Textural class & Clay & Silt & $\begin{array}{l}\text { Sand } \\
(\mathrm{g} / \mathrm{kg})\end{array}$ & Organic matter & $\begin{array}{c}\text { Bulk density } \\
\left(\mathrm{g} / \mathrm{cm}^{3}\right)\end{array}$ \\
\hline SW summit & Silt loam & $56.7^{\mathrm{d}}$ & $746.7^{\mathrm{a}}$ & $196.7^{c}$ & $35.3^{\mathrm{d}}$ & $1.12^{\mathrm{a}}$ \\
\hline SW backslope & Silt loam & $96.7^{c}$ & $616.7^{c}$ & $286.7^{\mathrm{b}}$ & $38.7^{\mathrm{cd}}$ & $1.04^{\mathrm{a}}$ \\
\hline SW toeslope & Clay loam & $286.7^{\mathrm{a}}$ & $323.3^{e}$ & $390.0^{\mathrm{a}}$ & $60.6^{\mathrm{a}}$ & $0.86^{\mathrm{b}}$ \\
\hline NE summit & Silt loam & $83.3^{\mathrm{cd}}$ & $690.0^{\mathrm{b}}$ & $226.7^{c}$ & $44.0^{\mathrm{bc}}$ & $1.09^{\mathrm{a}}$ \\
\hline NE backslope & Silt loam & $93.3^{c}$ & $640.0^{\mathrm{bc}}$ & $266.7^{\mathrm{b}}$ & $34.7^{\mathrm{d}}$ & $1.13^{\mathrm{a}}$ \\
\hline NE toeslope & Loam & $156.7^{\mathrm{b}}$ & $463.3^{\mathrm{d}}$ & $380.0^{\mathrm{a}}$ & $46.0^{\mathrm{b}}$ & $1.05^{\mathrm{a}}$ \\
\hline
\end{tabular}

Soil property means within a column, followed by different letters are significantly different at $P \leq 0.05$ according to Fisher's protected LSD.

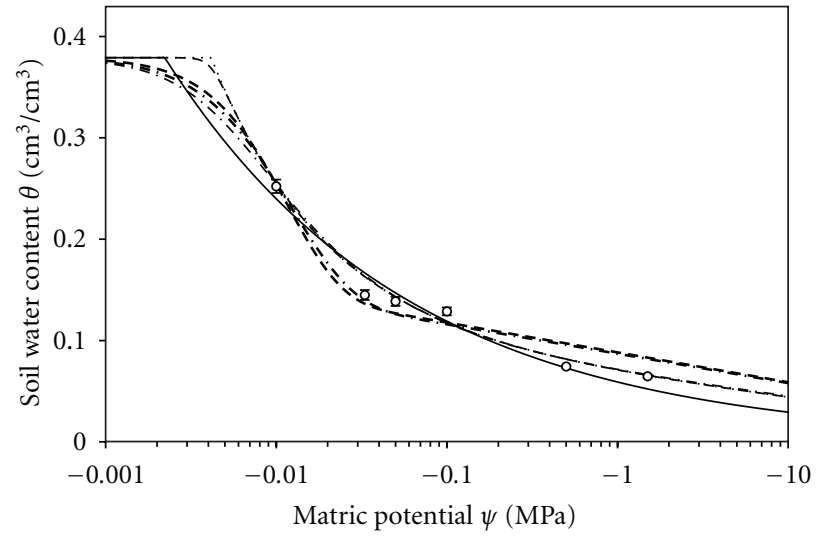

(a) Summit

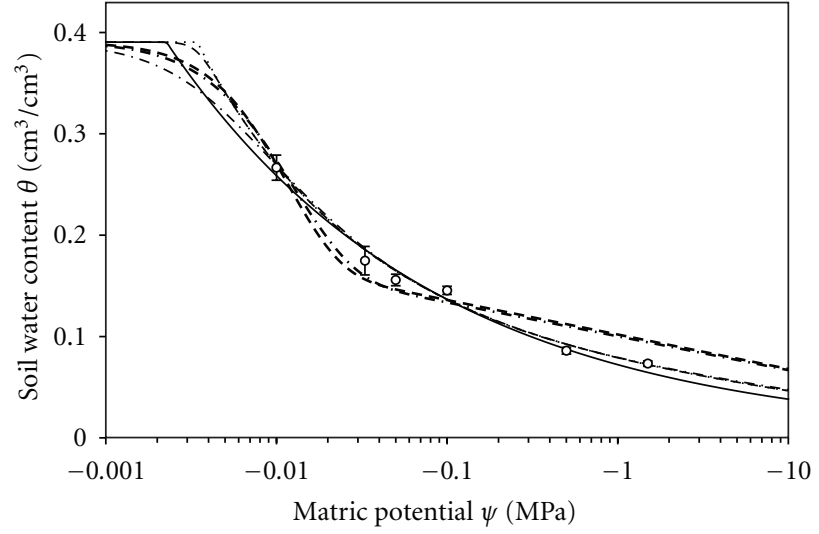

(b) Backslope

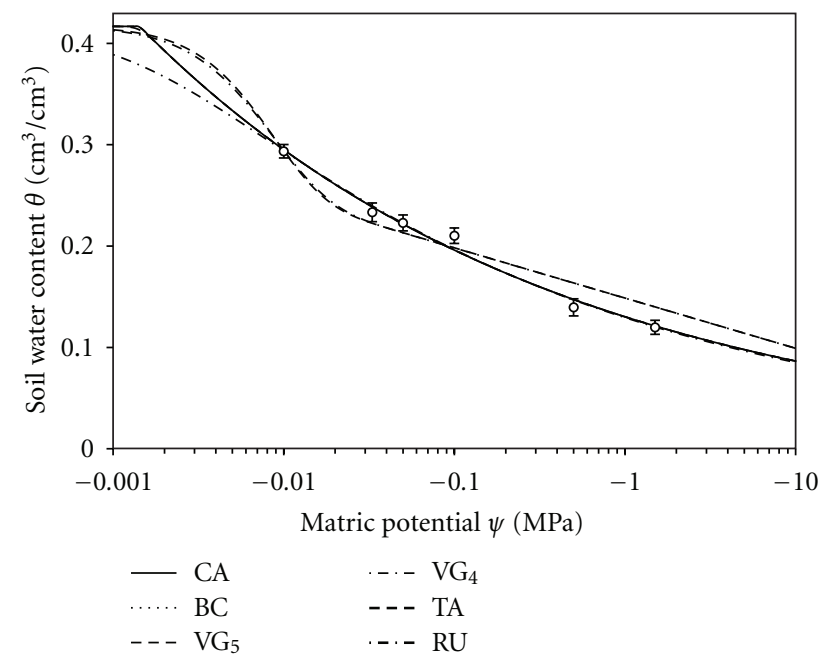

(c) Toeslope

FIGURE 2: Fitted SWRC for soil water contents $(\theta)$ at soil matric potentials $(\psi)$ for the (a) summit, (b) backslope, and (c) toeslope positions averaged across two hillslopes using the Campbell (CA) model with absent $\theta_{r}$ parameter, and Brooks-Corey (BC), five- and four-parameter van Genuchten $\left(\mathrm{VG}_{5}\right.$ and $\mathrm{VG}_{4}$ ), Tani (TA), and Russo (RU) models with $\theta_{r}$ modified by a logarithmic equation describing the adsorption of water on soil in the dry range of the retention curve. Error bars are SE for six water retention measurements.

$\theta_{r}$ as a free parameter provided better fit particularly in the dry range of the curve compared to $\theta_{r(W)}$ values (Figures $1-3)$. Models containing the modified form of $\theta_{r}$ retain the form of the original model in the wet range of the curve and the form of the logarithmic adsorption equation in the dry range [28]. The $\mathrm{BC}$ and VG models showed marginal improvement of fit when $\theta_{r}$ was modified rather than estimated. The TA and RU models, however, had considerably improved fit with $\theta_{r(M)}$ compared to $\theta_{r(E)}$ mainly in the dry range of the curve (Figures 2 and 3 ). 
TABLE 2: Average fitted parameter and AIC values for the soil water retention models across hillslopes.

\begin{tabular}{|c|c|c|c|c|c|c|c|c|}
\hline \multicolumn{2}{|l|}{ Hillslope position } & \multicolumn{6}{|c|}{ Average parameter values (SE) } & \multirow[t]{2}{*}{$\mathrm{AIC}^{\mathrm{g}}$} \\
\hline$\theta_{r}$ derivation & Model & \multicolumn{2}{|c|}{$\left(\mathrm{cm}^{3} / \mathrm{cm}^{3}\right)$} & $P_{1}^{\mathrm{c}}$ & $P_{2}^{\mathrm{d}}$ & (dimensionless) & aless) & \\
\hline Summit & & 0.379 & & & & & & \\
\hline Absent & $\mathrm{CA}$ & & $0.000(-)$ & $-0.0022(0.0006)$ & - & $3.29(0.34)$ & - & -27.6 \\
\hline \multirow[t]{5}{*}{ Measured } & $\mathrm{BC}$ & & $0.065(-)$ & $-0.0042(0.0006)$ & - & $0.60(0.05)$ & - & -28.5 \\
\hline & $\mathrm{VG}_{5}$ & & $0.065(-)$ & - & $-0.0042(0.0006)$ & $11.14(0.04)$ & $0.054(0.005)$ & -26.5 \\
\hline & $\mathrm{VG}_{4}$ & & $0.065(-)$ & - & $-0.0053(0.0010)$ & $1.65(0.07)$ & - & -28.1 \\
\hline & $\mathrm{TA}$ & & $0.065(-)$ & - & $-0.0115(0.0035)$ & - & - & -11.1 \\
\hline & RU & & $0.065(-)$ & $-0.0011(<.0001)$ & - & $16.66(5.07)$ & - & -13.5 \\
\hline \multirow[t]{5}{*}{ Modified } & $\mathrm{BC}$ & & $0.064(0.011)$ & $-0.0042(0.0008)$ & - & $0.69(0.16)$ & - & -30.1 \\
\hline & $\mathrm{VG}_{5}$ & & $0.064(0.008)$ & - & $-0.0042(<.0001)$ & $11.83(<.01)$ & $0.059(0.006)$ & -28.1 \\
\hline & $\mathrm{VG}_{4}$ & & $0.066(0.011)$ & - & $-0.0053(0.0012)$ & $1.79(0.20)$ & - & -29.4 \\
\hline & $\mathrm{TA}$ & & $0.088(0.005)$ & - & $-0.0055(0.0007)$ & - & - & -24.1 \\
\hline & RU & & $0.087(0.005)$ & $-0.0011(<.0001)$ & - & $5.43(1.40)$ & - & -24.5 \\
\hline \multirow[t]{5}{*}{ Estimated } & $\mathrm{BC}$ & & $0.051(0.015)$ & $-0.0037(0.0007)$ & - & $0.51(0.10)$ & - & -29.4 \\
\hline & $\mathrm{VG}_{5}$ & & $0.051(0.011)$ & - & $-0.0037(<.0001)$ & $11.05(<.01)$ & $0.046(0.004)$ & -27.4 \\
\hline & $\mathrm{VG}_{4}$ & & $0.055(0.015)$ & - & $-0.0048(0.0012)$ & $1.58(0.13)$ & - & -28.5 \\
\hline & $\mathrm{TA}$ & & $0.106(0.014)$ & - & $-0.0070(0.0019)$ & - & - & -15.6 \\
\hline & RU & & $0.098(0.015)$ & $-0.0011(<.0001)$ & - & $9.93(4.11)$ & - & -16.8 \\
\hline Backslope & & 0.391 & & & & & & \\
\hline Absent & $\mathrm{CA}$ & & $0.000(-)$ & $-0.0023(0.0004)$ & - & $3.61(0.23)$ & - & -32.1 \\
\hline \multirow[t]{5}{*}{ Measured } & $\mathrm{BC}$ & & $0.073(-)$ & $-0.0040(0.0006)$ & - & $0.54(0.04)$ & - & -28.8 \\
\hline & $\mathrm{VG}_{5}$ & & $0.073(-)$ & - & $-0.0040(0.0006)$ & $21.21(0.05)$ & $0.025(0.002)$ & -26.8 \\
\hline & $\mathrm{VG}_{4}$ & & $0.073(-)$ & - & $-0.0053(0.0009)$ & $1.59(0.06)$ & - & -29.4 \\
\hline & $\mathrm{TA}$ & & $0.073(-)$ & - & $-0.0140(0.0008)$ & - & - & -10.2 \\
\hline & RU & & $0.073(-)$ & $-0.0011(<.0001)$ & - & $20.87(6.05)$ & - & -12.8 \\
\hline \multirow[t]{5}{*}{ Modified } & $\mathrm{BC}$ & & $0.061(0.014)$ & $-0.0034(0.0006)$ & - & $0.51(0.10)$ & - & -33.6 \\
\hline & $\mathrm{VG}_{5}$ & & $0.061(0.010)$ & - & $-0.0034(<.0001)$ & $9.68(<.01)$ & $0.052(0.005)$ & -31.6 \\
\hline & $\mathrm{VG}_{4}$ & & $0.066(0.009)$ & - & $-0.0044(<.0001)$ & $1.58(0.06)$ & - & -32.9 \\
\hline & $\mathrm{TA}$ & & $0.102(0.006)$ & - & $-0.0055(0.0009)$ & - & - & -21.9 \\
\hline & RU & & $0.100(0.007)$ & $-0.0011(<.0001)$ & - & $5.57(1.94)$ & - & -22.5 \\
\hline \multirow[t]{5}{*}{ Estimated } & $\mathrm{BC}$ & & $0.042(0.015)$ & $-0.0032(0.0005)$ & - & $0.39(0.06)$ & - & -33.3 \\
\hline & $\mathrm{VG}_{5}$ & & $0.042(0.011)$ & - & $-0.0032(<.0001)$ & $9.38(<.01)$ & $0.042(0.003)$ & -31.3 \\
\hline & $\mathrm{VG}_{4}$ & & $0.049(0.011)$ & - & $-0.0042(<.0001)$ & $1.45(0.03)$ & - & -32.3 \\
\hline & $\mathrm{TA}$ & & $0.120(0.018)$ & - & $-0.0078(0.0031)$ & - & - & -13.6 \\
\hline & RU & & $0.108(0.019)$ & $-0.0011(<.0001)$ & - & $13.00(5.66)$ & - & -15.4 \\
\hline Toeslope & & 0.417 & & & & & & \\
\hline Absent & $\mathrm{CA}$ & & $0.000(-)$ & $-0.0014(0.0003)$ & - & $5.63(0.30)$ & - & -34.5 \\
\hline \multirow[t]{5}{*}{ Measured } & $\mathrm{BC}$ & & $0.120(-)$ & $-0.0030(0.0009)$ & - & $0.41(0.06)$ & - & -23.3 \\
\hline & $\mathrm{VG}_{5}$ & & $0.120(-)$ & - & $-0.0030(0.0009)$ & $19.63(0.33)$ & $0.021(0.003)$ & -21.3 \\
\hline & $\mathrm{VG}_{4}$ & & $0.120(-)$ & - & $-0.0039(0.0013)$ & $1.44(0.07)$ & - & -24.0 \\
\hline & $\mathrm{TA}$ & & $0.120(-)$ & - & $-0.0177(0.0057)$ & - & - & -8.1 \\
\hline & RU & & $0.120(-)$ & $-0.0011(<.0001)$ & - & $29.02(10.26)$ & - & -10.5 \\
\hline \multirow[t]{5}{*}{ Modified } & $\mathrm{BC}$ & & $0.000(-)$ & $-0.0014(0.0003)$ & - & $0.18(0.01)$ & - & -32.5 \\
\hline & $\mathrm{VG}_{5}$ & & $0.000(-)$ & - & $-0.0014(<.0001)$ & $14.34(0.24)$ & $0.012(<.001)$ & -30.5 \\
\hline & $\mathrm{VG}_{4}$ & & $0.000(-)$ & - & $-0.0016(<.0001)$ & $1.18(<.01)$ & - & -32.8 \\
\hline & $\mathrm{TA}$ & & $0.149(0.005)$ & - & $-0.0039(0.0008)$ & - & - & -23.4 \\
\hline & RU & & $0.149(0.005)$ & $-0.0011(<.0001)$ & - & $2.35(1.23)$ & - & -23.4 \\
\hline
\end{tabular}


TABle 2: Continued.

\begin{tabular}{|c|c|c|c|c|c|c|c|c|}
\hline \multirow{2}{*}{$\begin{array}{l}\text { Hillslope position } \\
\qquad \theta_{r} \text { derivation }\end{array}$} & \multirow[b]{2}{*}{ Model } & \multicolumn{6}{|c|}{ Average parameter values (SE) } & \multirow[t]{2}{*}{$\mathrm{AIC}^{\mathrm{g}}$} \\
\hline & & $\theta_{s}{ }^{\mathrm{a}}$ & $\begin{array}{r}\theta_{r}{ }^{\mathrm{b}} \\
\left(\mathrm{cm}^{3} / \mathrm{cm}^{3}\right) \\
\end{array}$ & $P_{1}^{\mathrm{c}}$ & $\mathrm{Pa})$ & \multicolumn{2}{|c|}{ (dimensionless) } & \\
\hline \multirow[t]{5}{*}{ Estimated } & $\mathrm{BC}$ & & $0.000(-)$ & $-0.0014(0.0003)$ & - & $0.18(0.01)$ & - & -32.5 \\
\hline & $\mathrm{VG}_{5}$ & & $0.000(-)$ & - & $-0.0014(<.0001)$ & $14.45(1.64)$ & $0.012(0.001)$ & -30.5 \\
\hline & $\mathrm{VG}_{4}$ & & $0.000(-)$ & - & $-0.0016(<.0001)$ & $1.18(<.01)$ & - & -32.8 \\
\hline & TA & & $0.182(0.020)$ & - & $-0.0065(0.0019)$ & - & - & -11.3 \\
\hline & RU & & $0.162(0.028)$ & $-0.0011(<.0001)$ & - & $15.39(10.95)$ & - & -12.4 \\
\hline
\end{tabular}

${ }^{\mathrm{a}} \theta_{s}$ is measured saturation water content.

${ }^{\mathrm{b}} \theta_{r}$ is residual water content.

${ }^{\mathrm{c}} P_{1}$ is the air entry matric suction ( $\psi_{e}, \psi_{e}$, and $\alpha^{-1}$ of the CA, BC, and RU models, resp.).

${ }^{\mathrm{d}} P_{2}$ is the capillary pressure at the inflection point on the water retention curve $\left(\alpha^{-1}, \alpha^{-1}\right.$, and $\psi_{o}$ of the $\mathrm{VG}_{5}, \mathrm{VG}_{4}$, and TA models, resp.).

${ }^{\mathrm{e}} P_{3}$ is a dimensionless parameter ( $\beta, \lambda, n, n$, and $m$ of the $\mathrm{CA}, \mathrm{BC}, \mathrm{VG}_{5}, \mathrm{VG}_{4}$, and $\mathrm{RU}$ models, resp.).

${ }^{\mathrm{f}} P_{4}$ is a dimensionless parameter ( $m$ of the $\mathrm{VG}_{5}$ model).

$\mathrm{g}_{\mathrm{A}}$ lower value of Akaike Information Criterion (AIC) indicates a better model fit.

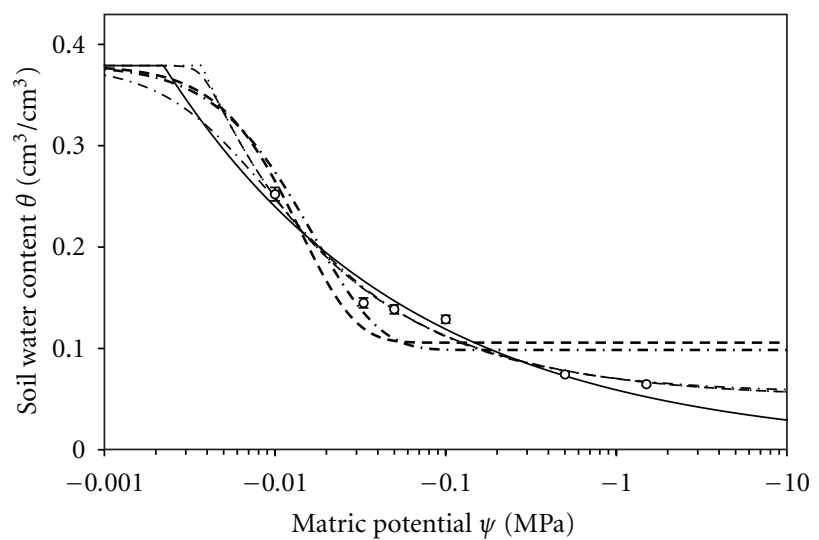

(a) Summit

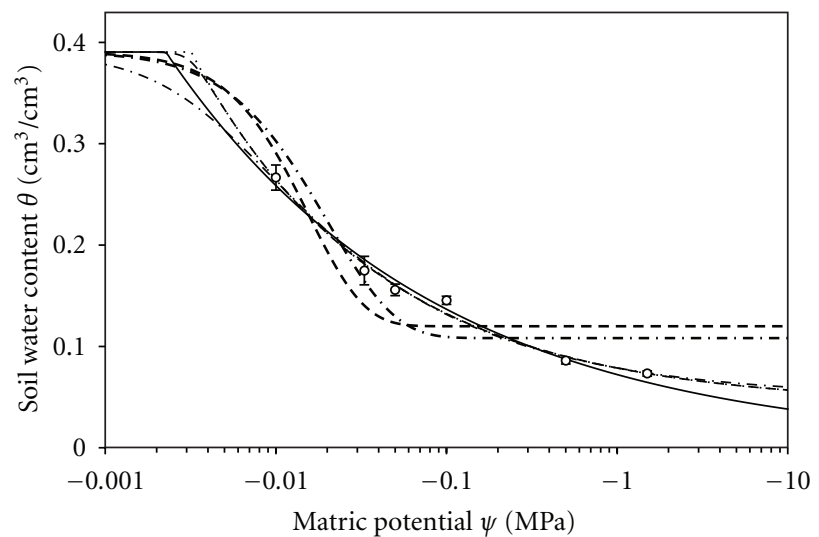

(b) Backslope

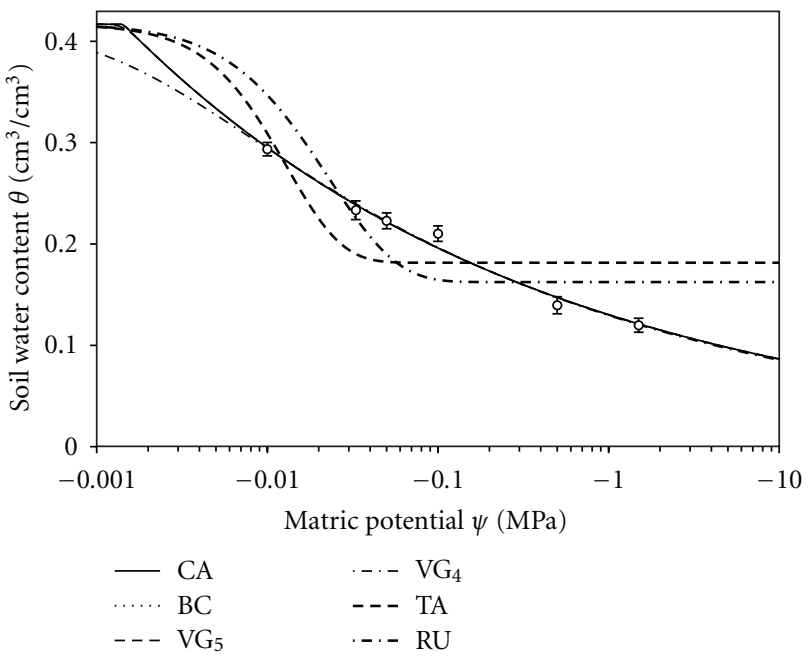

(c) Toeslope

FIGURE 3: Fitted SWRC for soil water contents $(\theta)$ at soil matric potentials $(\psi)$ for the (a) summit, (b) backslope, and (c) toeslope positions averaged across two hillslopes using the Campbell (CA) model with absent $\theta_{r}$ parameter, and Brooks-Corey (BC), five- and four-parameter van Genuchten $\left(\mathrm{VG}_{5}\right.$ and $\mathrm{VG}_{4}$ ), Tani (TA), and Russo (RU) models with $\theta_{r}$ estimated as one of the fitted parameters. Error bars are SE for six water retention measurements. 
TABLE 3: Akaike weights and evidence ratios for the soil water retention models.

\begin{tabular}{|c|c|c|c|}
\hline $\begin{array}{c}\theta_{r} \text { derivation } \\
\text { Model }\end{array}$ & Akaike weight ${ }^{\mathrm{a}}$ & Evidence ratio ${ }^{\mathrm{b}}$ & Rank \\
\hline \multicolumn{4}{|l|}{ Absent } \\
\hline $\mathrm{CA}$ & 0.143 & 1.4 & 4 \\
\hline \multicolumn{4}{|l|}{ Measured } \\
\hline $\mathrm{BC}$ & 0.015 & 13.2 & 9 \\
\hline $\mathrm{VG}_{5}$ & 0.006 & 35.9 & 10 \\
\hline $\mathrm{VG}_{4}$ & 0.018 & 11.4 & 8 \\
\hline $\mathrm{TA}$ & 0.000 & $67,045.1$ & 16 \\
\hline RU & 0.000 & $19,531.6$ & 15 \\
\hline \multicolumn{4}{|l|}{ Modified } \\
\hline $\mathrm{BC}$ & 0.203 & 1.0 & 1 \\
\hline $\mathrm{VG}_{5}$ & 0.075 & 2.7 & 6 \\
\hline $\mathrm{VG}_{4}$ & 0.169 & 1.2 & 3 \\
\hline $\mathrm{TA}$ & 0.002 & 85.3 & 12 \\
\hline $\mathrm{RU}$ & 0.003 & 72.2 & 11 \\
\hline \multicolumn{4}{|l|}{ Estimated } \\
\hline $\mathrm{BC}$ & 0.172 & 1.2 & 2 \\
\hline $\mathrm{VG}_{5}$ & 0.063 & 3.1 & 7 \\
\hline $\mathrm{VG}_{4}$ & 0.132 & 1.5 & 5 \\
\hline $\mathrm{TA}$ & 0.000 & $10,542.0$ & 14 \\
\hline RU & 0.000 & $5,323.0$ & 13 \\
\hline
\end{tabular}

${ }^{a}$ Akaike weight $\left(w_{i}\right)$ is based on average AIC value across all hillslope positions.

${ }^{\mathrm{b}}$ Evidence ratio $\left(w_{i} / w_{j}\right)$ is based on $w_{i}$ from average AIC values, where model $i$ is the best-fitting model (BC model with modified $\theta_{r}$ ), and $j$ indexes the remaining models in the set.

The evidence ratio provided a discrete comparison of the water retention models in a pairwise manner. The water retention models were compared to the $\mathrm{BC}$ model with $\theta_{r(M)}$, which was the best-fitting model based on $w_{i}$ derived from average AIC values (Table 3 ). An evidence ratio of 3 or less in relation to another model provides little evidence that model $i$ is superior [31]. Accordingly, BC with $\theta_{r(M)}$ and $\theta_{r(E)}, \mathrm{VG}_{4}$ with $\theta_{r(M)}$ and $\theta_{r(E)}$, and CA models would serve nearly equally well in approximating the water retention information.

The $\mathrm{BC}$ and $\mathrm{VG}_{5}$ models represented the SWRC similarly except at the wetter end of the curve, where $d \theta / d \psi$ for the BC model was discontinuous (Figure 1). The BC model had lower AIC values (Table 2), which reflected parsimony in the number of parameters for the $\mathrm{BC}$ model. However, the $\mathrm{CA}$ and $\mathrm{BC}$ models represent the SWRC with additional complexity due to discontinuous $d \theta / d \psi$, where $\psi \geq \psi_{e}$.

The $\mathrm{BC}$ and $\mathrm{VG}_{4}$ models with $\theta_{r(E)}$ fit the SWRC nearly identical to one another between -0.01 and $-1.5 \mathrm{MPa}$ (Figure 3). The CA model was considered among the best models, due at least in part to its parsimonious equation. However, the CA model generally underestimated water retention less than approximately $-0.5 \mathrm{MPa}$ for the summit and backslope positions, compared to the $\mathrm{BC}$ and $\mathrm{VG}$ models.

The $\mathrm{VG}_{5}$ model with modified and estimated forms of $\theta_{r}$ would be only slightly less adequate in describing the water retention relationship compared to the highest ranking five models (Table 3 ). The TA and RU models consistently had relatively high evidence ratios, particularly for the measured and estimated derivations of $\theta_{r}$, indicating low prediction ability for the SWRC compared to the other models. Nonetheless, the TA and RU models were generally adequate to represent $\theta(\psi)$ at field capacity $(-0.033 \mathrm{MPa})$. The TA and RU models also estimated water retention fairly well at $-1.5 \mathrm{MPa}$, but only when the measured form of $\theta_{r}$ was used.

The CA and BC models may provide unrealistic description of water retention at the wet end of the SWRC where $d \theta / d \psi$ is modelled as a discontinuous function $[36,37]$. The continuous VG models contain an inflection point enabling better representation of water retention near saturation [36]. However, the ability of the $\mathrm{VG}_{4}$ model to predict $d \theta / d \psi$ as a continuous function did not provide superior fit compared to the CA and BC models (Table 3). Regardless, the minimum threshold water potential for cessation of germination in most weed species is less than $-0.1 \mathrm{MPa}$ (Table 4 ).

The $\mathrm{VG}_{4}$ model was superior to the $\mathrm{VG}_{5}$ model no matter which derivation of $\theta_{r}$ was used (Table 3 ). The $\mathrm{VG}_{4}$ model has one less parameter making it more parsimonious than the $\mathrm{VG}_{5}$ model. The $\mathrm{VG}_{4}$ model may also provide a superior estimation of the water retention relationships compared to the $\mathrm{VG}_{5}$ model due to independence of the $n$ and $m$ parameters in the $\mathrm{VG}_{5}$ model, that can lead to 
TABLE 4: Minimum threshold water potential for germination of weed species grouped by intervals of germination sensitivity to water potential.

\begin{tabular}{|c|c|c|c|}
\hline $\begin{array}{l}\text { Sensitivity interval (MPa) } \\
\text { Minimum threshold } \\
(\mathrm{MPa})\end{array}$ & Common name & Scientific name & Reference \\
\hline \multicolumn{4}{|l|}{$\mathrm{B}(-0.1$ to -0.5$)$} \\
\hline-0.10 & Common cocklebur & Xanthium strumarium $\mathrm{L}$. & {$[6]$} \\
\hline-0.20 & Redroot pigweed & Amaranthus retroflexus $\mathrm{L}$. & {$[38]$} \\
\hline \multicolumn{4}{|l|}{$\mathrm{C}(-0.5$ to -1.0$)$} \\
\hline-0.50 & Common groundsel & Senecio vulgaris $\mathrm{L}$. & [39] \\
\hline-0.50 & Large crabgrass & Digitaria sanguinalis (L.) Scop. & [40] \\
\hline-0.60 & Wild oat & Avena fatua $\mathrm{L}$. & {$[41]$} \\
\hline-0.64 & Common lambsquarters & Chenopodium album $\mathrm{L}$. & {$[42]$} \\
\hline-0.64 & Velvetleaf & Abutilon theophrasti Medik. & {$[43]$} \\
\hline-0.69 & Yellow foxtail & Setaria glauca (L.) Beauv. & {$[5]$} \\
\hline-0.70 & Green foxtail & Setaria viridis (L.) Beauv. & [5] \\
\hline-0.80 & Goosegrass & Eleusine indica (L.) Gaertn. & {$[44]$} \\
\hline-0.80 & Common ragweed & Ambrosia artemisiifolia $\mathrm{L}$. & {$[45]$} \\
\hline-0.83 & Large crabgrass & Digitaria sanguinalis (L.) Scop. & [5] \\
\hline \multicolumn{4}{|l|}{$\mathrm{D}(-1.0$ to -1.5$)$} \\
\hline-1.13 & Common chickweed & Stellaria media (L.) Vill. & {$[46]$} \\
\hline-1.15 & Rigid ryegrass & Lolium rigidum Gaudin & {$[47]$} \\
\hline-1.20 & Wild oat & Avena fatua $\mathrm{L}$. & {$[48]$} \\
\hline-1.21 & Goosegrass & Eleusine indica (L.) Gaertn. & {$[5]$} \\
\hline-1.50 & Wild oat & Avena fatua $\mathrm{L}$. & {$[49]$} \\
\hline-1.50 & Perennial ryegrass & Lolium perenne $\mathrm{L}$. & {$[50]$} \\
\hline-1.53 & Blackgrass & Alopecurus myosuroides Huds. & {$[51]$} \\
\hline
\end{tabular}

distinctiveness problems in the estimation process, resulting in a less accurate description of the SWRC in the dry range [52].

The SWRC for the coarse soils in the summit and backslope positions were best described by the $\mathrm{BC}$ model, based on $w_{i}$ values. The CA model had the best fit to the data for the soils with greater clay content in the toeslope position (Table 2).

3.3. Weed Seed Germination Sensitivity to Soil Water Potential. The measured water potential interval $(-0.01$ to $-1.5 \mathrm{MPa})$ was divided into four subintervals to represent sensitivity groups of minimum threshold water potential for germination of weed species (Table 4). No species from the literature had a minimum threshold water potential within interval A ( -0.01 to $-0.1 \mathrm{MPa})$. The minimum threshold water potential for germination ranged from high sensitivity (interval B) to low sensitivity (interval D).

The best-fitting SWRC for each model from the various $\theta_{r}$ derivations was retained to evaluate water potential intervals for seed germination. Models evaluated were CA with no $\theta_{r}$ parameter, and $\mathrm{BC}, \mathrm{VG}_{5}, \mathrm{VG}_{4}, \mathrm{TA}$ and $\mathrm{RU}$ models with modified $\theta_{r}$.

The mean water content was averaged across hillslopes because water retention was not different between hillslopes (Table 5). Similar mean water contents for the water potential intervals for the summit and backslope positions occurred as a result of few differences in the underlying soil physical properties between these two hillslope positions (Table 1). The upper hillslope positions differed from the toeslope as a result of differences in soil physical properties that influence the SWRC. The summit and backslope positions contained silt loam soils, whereas the toeslopes had loam and clay loam soils with greater OM content.

The interactions for hillslope position by SWRC model are shown in Figure 4. The $\mathrm{VG}_{4}$ models did not differ from the $\mathrm{BC}$ model for any water potential interval in either the upper or lower hillslope. The CA model overestimated water retention between -0.01 to $-0.1 \mathrm{MPa}$ for the upper hillslope (Figures 4(a) and 4(b)). Since interval A does not contain minimum threshold water potential for weed seed germination, deviations from the measured water retention data in interval A would not be expected to influence seed germination of any of the species listed in Table 4. Deviations in water retention by the CA model were confined to the upper hillslope.

The CA model underestimated water retention at a potential less than $-0.5 \mathrm{MPa}$ for the summit and backslope positions (Figures 4(a) and 4(b)). An underestimation in water retention less than $-0.5 \mathrm{MPa}$ would result in an underestimation in predicted germination for weeds with minimum threshold water potential less than $-0.5 \mathrm{MPa}$. 


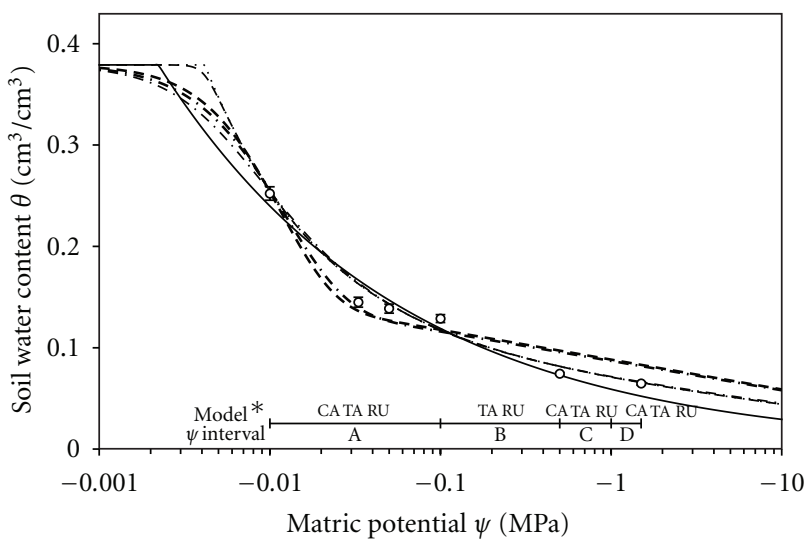

(a) Summit

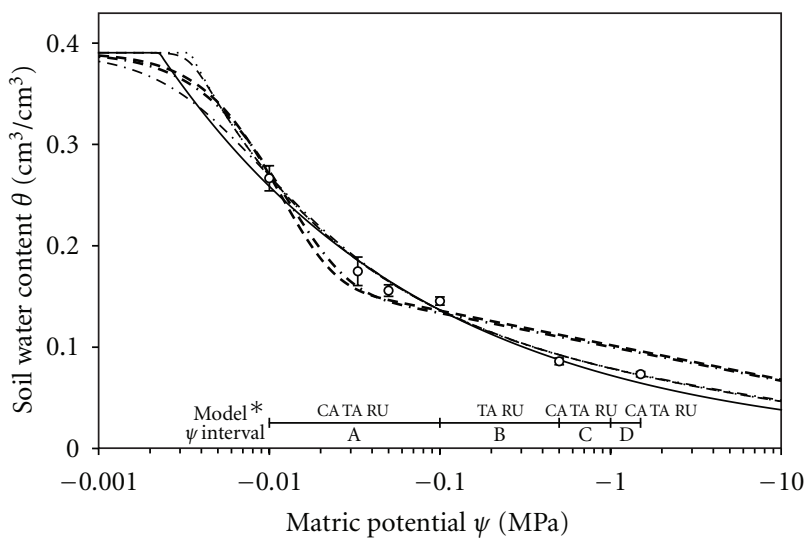

(b) Backslope

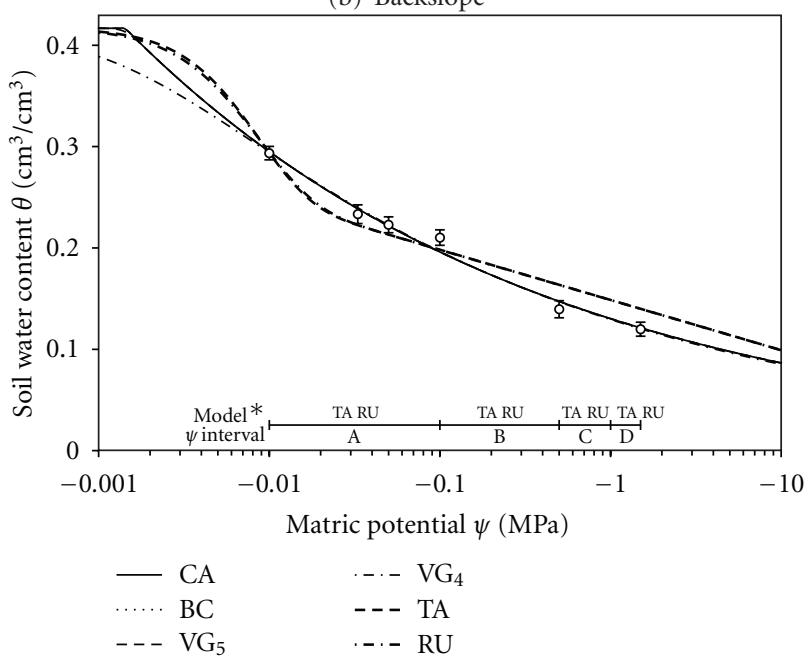

(c) Toeslope

Figure 4: Fitted SWRC for soil water contents $(\theta)$ at soil matric potentials $(\psi)$ for the (a) summit, (b) backslope, and (c) toeslope positions using the Campbell (CA) model with absent $\theta_{r}$ parameter, and Brooks-Corey (BC), five- and four-parameter van Genuchten $\left(\mathrm{VG}_{5}\right.$ and $\mathrm{VG}_{4}$ ), Tani (TA), and Russo (RU) models with $\theta_{r}$ modified as one of the fitted parameters. Hillslopes are averaged. Error bars are SE for six water retention measurements. Model* represents SWRC models that have significantly different water retention within a water potential interval compared to the $\mathrm{BC}$ model. Water potential $(\psi)$ intervals $\mathrm{A}$ : -0.01 to $-0.1 \mathrm{MPa}$; $\mathrm{B}$ : -0.1 to $-0.5 \mathrm{MPa}$; : -0.5 to $-1.0 \mathrm{MPa}$; $:-1.0$ to $-1.5 \mathrm{MPa}$ represent groups of minimum threshold water potential sensitivity for germination.
However, because soil water is generally measured in the field on a content basis, and SWRC are used to translate water content to a potential basis, the CA model would predict higher water potential for a given field water content compared to the BC or VG models. This case would overestimate germination of weeds that have minimum threshold water potential less than $-0.5 \mathrm{MPa}$. Thus, germination would be predicted for species that would otherwise not occur in the upper hillslope. For example, at the summit, soil with a water content of $0.07 \mathrm{~cm}^{3} / \mathrm{cm}^{3}$ would have water potentials of $-1.08 \mathrm{MPa}$ and $-0.57 \mathrm{MPa}$ predicted by the $\mathrm{BC}$ and CA models, respectively. The $\mathrm{BC}$ model would predict germination of weeds only for interval D in Table 4, whereas the CA model would predict germination of weeds for interval D and almost all of interval C.

The mean water content of the TA and RU models differed from that of the $\mathrm{BC}$ model across all water potential intervals for both upper and lower hillslope positions (Figure 4). Water retention was underestimated by the TA and RU models for the -0.01 to $-0.1 \mathrm{MPa}$ interval, which would not be expected to influence modelling of germination for weeds listed in Table 4. However, overestimation of water retention by the TA and RU models for soils drier than $-0.1 \mathrm{MPa}$ would result in overestimation of seed germination at specific potentials. On a field water content basis, this would result in underestimation of seed germination by all species listed in Table 4 . For instance, at the toeslope position, a soil water content of $0.15 \mathrm{~cm}^{3} / \mathrm{cm}^{3}$ would have a predicted water potential of $-0.45 \mathrm{MPa}$ with the $\mathrm{BC}$ model and $-0.94 \mathrm{MPa}$ with the TA model (Figure 4(c)). The BC model would, therefore, predict germination of weeds for intervals $\mathrm{C}$ and $\mathrm{D}$, whereas the TA model would predict germination of weeds for only interval D. Predictions of weed seed germination from a range of minimum threshold water potentials are clearly dependent on the fit of the SWRC model.

\section{Conclusion}

Models of the SWRC with derivations of $\theta_{r}$ were developed to describe the water retention properties of the shallow seedling recruitment zone. Soils along the hillslopes in this study had diverse underlying soil physical properties that influence the SWRC. Soil topographical relationships for the physical properties that affect the SWRC allowed hillslope positions to be used as categorical units for describing the SWRC.

Evaluation of analytical models to describe the SWRC of the shallow seedling recruitment zone indicated that the $\mathrm{BC}$, $\mathrm{VG}_{4}$, and CA models with modified and estimated forms of $\theta_{r}$ were similar but superior to models with $\theta_{r}$ designated at $-1.5 \mathrm{MPa}$. However, when considering intervals of water potential, the CA model underestimated water retention for the upper hillslope at the dry end of the SWRC in the range for minimum threshold water potential for seed germination. Setting the residual water content at zero as in the case of the CA model will inevitably underestimate water content. The TA and RU models estimated water retention reasonably well at field capacity, but tended to overestimate water retention for the dry end of the SWRC. 
TABLE 5: Mean water content for water potential intervals based on weed seed germination sensitivity to water potential.

\begin{tabular}{|c|c|c|c|c|c|}
\hline \multirow[b]{2}{*}{ Main effect } & \multicolumn{5}{|c|}{$\begin{array}{c}\text { Mean water content } \\
\text { Water potential interval }(\mathrm{MPa})\end{array}$} \\
\hline & $\begin{array}{c}\text { Full } \\
-0.01 \text { to }-1.5\end{array}$ & $\begin{array}{c}\text { A } \\
-0.01 \text { to }-0.1\end{array}$ & $\begin{array}{c}\text { B } \\
-0.1 \text { to }-0.5 \\
\left(\mathrm{~cm}^{3} / \mathrm{cm}^{3}\right)\end{array}$ & $\begin{array}{c}\text { C } \\
-0.5 \text { to }-1.0\end{array}$ & $\begin{array}{c}\mathrm{D} \\
-1.0 \text { to }-1.5\end{array}$ \\
\hline \multicolumn{6}{|l|}{ Hillslope } \\
\hline SW & 0.158 & 0.202 & 0.132 & 0.108 & 0.098 \\
\hline $\mathrm{NE}$ & 0.150 & 0.190 & 0.126 & 0.102 & 0.092 \\
\hline \multicolumn{6}{|l|}{ Hillslope position } \\
\hline Summit & $0.124^{\mathrm{b}}$ & $0.164^{\mathrm{b}}$ & $0.099^{\mathrm{b}}$ & $0.080^{\mathrm{b}}$ & $0.072^{\mathrm{b}}$ \\
\hline Backslope & $0.141^{\mathrm{b}}$ & $0.185^{\mathrm{b}}$ & $0.114^{\mathrm{b}}$ & $0.091^{\mathrm{b}}$ & $0.082^{\mathrm{b}}$ \\
\hline Toeslope & $0.196^{\mathrm{a}}$ & $0.239^{\mathrm{a}}$ & $0.175^{\mathrm{a}}$ & $0.145^{\mathrm{a}}$ & $0.132^{\mathrm{a}}$ \\
\hline \multicolumn{6}{|l|}{ Model } \\
\hline $\mathrm{CA}$ & $0.153^{c}$ & $0.202^{\mathrm{a}}$ & $0.125^{\mathrm{d}}$ & $0.095^{\mathrm{c}}$ & $0.083^{c}$ \\
\hline $\mathrm{BC}$ & $0.153^{b c}$ & $0.198^{b}$ & $0.126^{c}$ & $0.100^{\mathrm{b}}$ & $0.090^{\mathrm{b}}$ \\
\hline $\mathrm{VG}_{5}$ & $0.153^{\mathrm{bc}}$ & $0.199^{\mathrm{b}}$ & $0.126^{\mathrm{c}}$ & $0.100^{\mathrm{b}}$ & $0.089^{\mathrm{b}}$ \\
\hline $\mathrm{VG}_{4}$ & $0.153^{b}$ & $0.198^{b}$ & $0.126^{c}$ & $0.101^{\mathrm{b}}$ & $0.091^{b}$ \\
\hline $\mathrm{TA}$ & $0.156^{\mathrm{a}}$ & $0.189^{d}$ & $0.137^{\mathrm{a}}$ & $0.118^{\mathrm{a}}$ & $0.109^{\mathrm{a}}$ \\
\hline $\mathrm{RU}$ & $0.156^{\mathrm{a}}$ & $0.191^{\mathrm{c}}$ & $0.135^{\mathrm{b}}$ & $0.116^{\mathrm{a}}$ & $0.108^{\mathrm{a}}$ \\
\hline Source of variation & & & $P>F$ & & \\
\hline Hillslope $(H)$ & 0.216 & 0.189 & 0.313 & 0.243 & 0.222 \\
\hline Position $(P)$ & $<.001$ & $<.001$ & $<.001$ & $<.001$ & $<.001$ \\
\hline$H \times P$ & 0.360 & 0.414 & 0.161 & 0.095 & 0.078 \\
\hline Model $(M)$ & $<.001$ & $<.001$ & $<.001$ & $<.001$ & $<.001$ \\
\hline$H \times M$ & 0.001 & $<.001$ & $<.001$ & 0.003 & 0.013 \\
\hline$P \times M$ & $<.001$ & 0.010 & 0.429 & $<.001$ & $<.001$ \\
\hline$H \times P \times M$ & $<.001$ & 0.431 & 0.682 & 0.411 & 0.309 \\
\hline
\end{tabular}

Means within a column and main effect, followed by different letters are significantly different at $P \leq 0.05$ according to Fisher's protected LSD.

Weed seed germination is generally predicted by models using hydrothermal properties of the soil environment, of which water potential is a component. Because the bestfitting SWRC is needed for a dynamic model to predict weed germination within the range of minimum threshold water potentials for germination, water retention models that specifically deal with the SWRC at the dry end of the curve need further investigation. Future efforts could include analysis of the SWRC below $-1.5 \mathrm{MPa}$ to include species with very low minimum threshold water potentials for germination. As well, future research could evaluate the SWRC for a range of soil textures beyond that examined in the current study.

The evaluated $\theta_{r}$ derivations showed that all models were best represented by specifying $\theta_{r}$ as a modified or estimated parameter. For modelling weed seed germination, it is most important to adequately describe the drier end of the SWRC below $-0.1 \mathrm{MPa}$. Accurate representation of the SWRC over the range of minimum threshold water potential for seed germination by modifying or estimating the $\theta_{r}$ parameter is necessary for modelling seed germination by avoiding deviations in estimated water potential and predicted seed germination.

\section{Acknowledgments}

This paper was funded by the Manitoba Rural Adaptation Council, the Natural Sciences and Engineering Research Council of Canada, and the Canadian Wheat Board.

\section{References}

[1] D. Hillel, "Soil water: content and potential," in Introduction to Soil Physics, D. Hillel, Ed., pp. 57-89, Academic Press, New York, NY, USA, 1982.

[2] R. R. Bruce and R. J. Luxmoore, "Water retention: field methods," in Methods of Soil Analysis, Part 1, Physical and Mineralogical Methods, G. S. Campbell, R. D. Jackson, M. M. Mortland, D. R. Nielsen, and A. Klute, Eds., pp. 663-686, Soil Science Society of America, Madison, Wisc, USA, 2nd edition, 1986.

[3] G. C. Topp, Y. T. Galganov, B. C. Ball, and M. R. Carter, "Soil water desorption curves," in Soil Sampling and Methods of Analysis, M. R. Carter, Ed., pp. 569-579, Lewis Publishers, Boca Raton, Fla, USA, 1993.

[4] K. J. Bradford, "Applications of hydrothermal time to quantifying and modeling seed germination and dormancy," Weed Science, vol. 50, no. 2, pp. 248-260, 2002. 
[5] R. Masin, M. C. Zuin, D. W. Archer, F. Forcella, and G. Zanin, "WeedTurf: a predictive model to aid control of annual summer weeds in turf," Weed Science, vol. 53, no. 2, pp. 193 201, 2005.

[6] J. K. Norsworthy and M. J. Oliveira, "A model for predicting common cocklebur (Xanthium strumarium) emergence in soybean," Weed Science, vol. 55, no. 4, pp. 341-345, 2007.

[7] P. J. Greminger, Y. K. Sud, and D. R. Nielsen, "Spatial variability of field-measured soil-water characteristics," Soil Science Society of America Journal, vol. 49, no. 5, pp. 10751082, 1985.

[8] D. S. Burden and H. M. Selim, "Correlation of spatially variable soil water retention for a surface soil," Soil Science, vol. 148, no. 6, pp. 436-447, 1989.

[9] M. Jauhiainen, Relationships of particle size distribution curve, soil water retention curve and unsaturated hydraulic conductivity and their implications on water balance of forested and agricultural hillslopes, Ph.D. thesis, Helsinki University of Technology, Espoo, Finland, 2002.

[10] M. D. Tomer, C. A. Cambardella, D. E. James, and T. B. Moorman, "Surface-soil properties and water contents across two watersheds with contrasting tillage histories," Soil Science Society of America Journal, vol. 70, no. 2, pp. 620-630, 2006.

[11] W. R. Kreznor, K. R. Olson, W. L. Banwart, and D. L. Johnson, "Soil, landscape, and erosion relationships in a northwest Illinois watershed," Soil Science Society of America Journal, vol. 53, no. 6, pp. 1763-1771, 1989.

[12] S. C. Brubaker, A. J. Jones, D. T. Lewis, and K. Frank, "Soil properties associated with landscape position," Soil Science Society of America Journal, vol. 57, no. 1, pp. 235-239, 1993.

[13] F. A. Ovalles and M. E. Collins, "Soil-landscape relationships and soil variability in north central Florida," Soil Science Society of America Journal, vol. 50, no. 2, pp. 401-408, 1986.

[14] R. H. Brooks and A. T. Corey, Hydraulic properties of porous media, Hydrology Paper no. 3, Colorado State University, Fort Collins, Colo, USA, 1964.

[15] M. T. van Genuchten, "A closed-form equation for predicting the hydraulic conductivity of unsaturated soils," Soil Science Society of America Journal, vol. 44, no. 5, pp. 892-898, 1980.

[16] M. J. Du Croix Sissons, R. C. Van Acker, D. A. Derksen, and A. G. Thomas, "Depth of seedling recruitment of five weed species measured in situ in conventional- and zero-tillage fields," Weed Science, vol. 48, no. 3, pp. 327-332, 2000.

[17] W. J. Bullied, R. C. Van Acker, and P. R. Bullock, "Hydrothermal modeling of seedling emergence timing across topography and soil depth," Agronomy Journal, vol. 104, no. 2, pp. 423436, 2012.

[18] W. J. Bullied, P. R. Bullock, and R. C. Van Acker, "Modeling the soil-water retention characteristic with pedotransfer functions for shallow seedling recruitment," Soil Science, vol. 176, no. 2, pp. 57-72, 2011.

[19] J. H. Dane and J. W. Hopmans, "Water retention and storage," in Methods of Soil Analysis: Physical Methods, J. H. Dane and G. C. Topp, Eds., pp. 671-690, Soil Science Society of America, Madison, Wisc, USA, 2002.

[20] G. W. Gee and D. Or, "Particle size analysis," in Methods of Soil Analysis: Physical Methods, J. H. Dane and G. C. Topp, Eds., pp. 255-293, Soil Science Society of America, Madison, Wisc, USA, 2002.

[21] J. A. McKeague, "Loss on ignition," in Manual on Soil Sampling and Methods of Analysis, Method 3.8, Canadian Society of Soil Science, Ottawa, Canada, 1978.

[22] SAS Institute, SAS/STAT User's guide, Version 9.1, SAS Institute Inc., Cary, NC, USA, 2004.
[23] G. S. Campbell, "A simple method for determining unsaturated conductivity from moisture retention data," Soil Science, vol. 117, no. 6, pp. 311-314, 1974.

[24] M. Tani, "The properties of water-table rise produced by a one-dimensional, vertical, unsaturated flow," Journal of Japan Forestry Society, vol. 64, pp. 409-418, 1982.

[25] D. Russo, "Determining soil hydraulic properties by parameter estimation: on the selection of a model for the hydraulic properties," Water Resources Research, vol. 24, no. 3, pp. 453459, 1988.

[26] Y. Mualem, "A new model for predicting the hydraulic conductivity of unsaturated porous media," Water Resources Research, vol. 12, no. 3, pp. 513-522, 1976.

[27] G. S. Campbell and S. Shiozawa, "Prediction of hydraulic properties of soils using particle-size distribution and bulk density data," in Proceedings of the International Workshop on Indirect Methods for Estimating the Hydraulic Properties of Unsaturated Soils, M. T. van Genuchten, R. J. Leij, and L. J. Lund, Eds., pp. 317-328, Riverside, Calif, USA, 1992.

[28] M. J. Fayer and C. S. Simmons, "Modified soil water retention functions for all matric suctions," Water Resources Research, vol. 31, no. 5, pp. 1233-1238, 1995.

[29] S. Matula, M. Mojrová, and K. Špongrová, "Estimation of the soil water retention curve (SWRC) using pedotransfer functions (PTFs)," Soil and Water Research, vol. 2, no. 4, pp. 113-122, 2007.

[30] H. Akaike, "A new look at the statistical model identification," IEEE Transactions on Automatic Control, vol. 19, no. 6, pp. 716-723, 1974.

[31] K. P. Burnham and D. R. Anderson, Model Selection and Multimodel Inference: A Practical Information-Theoretic Approach, Springer, New York, NY, USA, 2nd edition, 2002.

[32] W. M. Cornelis, M. Khlosi, R. Hartmann, M. Van Meirvenne, and B. De Vos, "Comparison of unimodal analytical expressions for the soil-water retention curve," Soil Science Society of America Journal, vol. 69, no. 6, pp. 1902-1911, 2005.

[33] H. Akaike, "A Bayesian analysis of the minimum AIC procedure," Annals of the Institute of Statistical Mathematics, vol. 30, no. 1, pp. 9-14, 1978.

[34] O. Tietje and M. Tapkenhinrichs, "Evaluation of pedo-transfer functions," Soil Science Society of America Journal, vol. 57, no. 4, pp. 1088-1095, 1993.

[35] D. D. Malo, B. K. Worchester, D. K. Cassel, and K. D. Matzdorf, "Soil-landscape relationships in a closed drainage system," Soil Science Society of America Proceedings, vol. 38, no. 5, pp. 813818, 1974.

[36] M. T. Van Genuchten and D. R. Nielsen, "On describing and predicting the hydraulic properties of unsaturated soils," Annales Geophysicae, vol. 3, no. 5, pp. 615-628, 1985.

[37] R. J. Lenhard, J. C. Parker, and S. Mishra, "On the correspondence between Brooks-Corey and van Genuchten models," Journal of Irrigation and Drainage Engineering, vol. 115, no. 4, pp. 744-751, 1989.

[38] R. Ghorbani, W. Seel, and C. Leifert, "Effects of environmental factors on germination and emergence of Amaranthus retroflexus," Weed Science, vol. 47, no. 5, pp. 505-510, 1999.

[39] M. McGiffen, K. Spokas, F. Forcella, D. Archer, S. Poppe, and R. Figueroa, "Emergence prediction of common groundsel (Senecio vulgaris)," Weed Science, vol. 56, no. 1, pp. 58-65, 2008.

[40] F. Forcella, R. L. Benech Arnold, R. Sanchez, and C. M. Ghersa, "Modeling seedling emergence," Field Crops Research, vol. 67, no. 2, pp. 123-139, 2000. 
[41] K. Martinson, B. Durgan, F. Forcella, J. Wiersma, K. Spokas, and D. Archer, "An emergence model for wild oat (Avena fatua)," Weed Science, vol. 55, no. 6, pp. 584-591, 2007.

[42] E. S. Roman, A. G. Thomas, S. D. Murphy, and C. J. Swanton, "Modeling germination and seedling elongation of common lambsquarters (Chenopodium album)," Weed Science, vol. 47, no. 2, pp. 149-155, 1999.

[43] J. Dorado, C. Fernández-Quintanilla, and A. C. Grundy, "Germination patterns in naturally chilled and nonchilled seeds of fierce thornapple (Datura ferox) and velvetleaf (Abutilon theophrasti)," Weed Science, vol. 57, no. 2, pp. 155-162, 2009.

[44] B. S. Ismail, T. S. Chuah, S. Salmijah, Y. T. Teng, and R. W. Schumacher, "Germination and seedling emergence of glyphosate-resistant and susceptible biotypes of goosegrass (Eleusine indica [L.] Gaertn.)," Weed Biology and Management, vol. 2, no. 4, pp. 177-185, 2002.

[45] A. Shrestha, E. S. Roman, A. G. Thomas, and C. J. Swanton, "Modeling germination and shoot-radicle elongation of Ambrosia artemisiifolia," Weed Science, vol. 47, no. 5, pp. 557$562,1999$.

[46] A. C. Grundy, K. Phelps, R. J. Reader, and S. Burston, "Modelling the germination of Stellaria media using the concept of hydrothermal time," New Phytologist, vol. 148, no. 3, pp. 433-444, 2000.

[47] M. Köchy and K. Tielbörger, "Hydrothermal time model of germination: parameters for 36 Mediterranean annual species based on a simplified approach," Basic and Applied Ecology, vol. 8, no. 2, pp. 171-182, 2007.

[48] E. R. Page, R. S. Gallagher, A. R. Kemanian, H. Zhang, and E. P. Fuerst, "Modeling site-specific wild oat (Avena fatua) emergence across a variable landscape," Weed Science, vol. 54, no. 5, pp. 838-846, 2006.

[49] C. Fernandez-Quinantilla, J. L. Gonzalez Andujar, and A. P. Appleby, "Characterization of the germination and emergence response to temperature and soil moisture of Avena fatua and A. sterilis," Weed Research, vol. 30, no. 4, pp. 289-295, 1990.

[50] J. R. McWilliam, R. J. Clements, and P. M. Dowling, "Some factors influencing the germination and early seedling development of pasture plants," Australian Journal of Agricultural Research, vol. 21, no. 1, pp. 19-32, 1970.

[51] N. Colbach, C. Dürr, B. Chauvel, and G. Richard, "Effect of environmental conditions on Alopecurus myosuroides germination. II. Effect of moisture conditions and storage length," Weed Research, vol. 42, no. 3, pp. 222-230, 2002.

[52] M. T. van Genuchten, F. J. Leij, and S. R. Yates, "The RETC code for quantifying the hydraulic functions of unsaturated soils," Report no. EPA/600/2-91/065, U.S. Environmental Protection Agency, Ada, Okla, USA, 1991. 

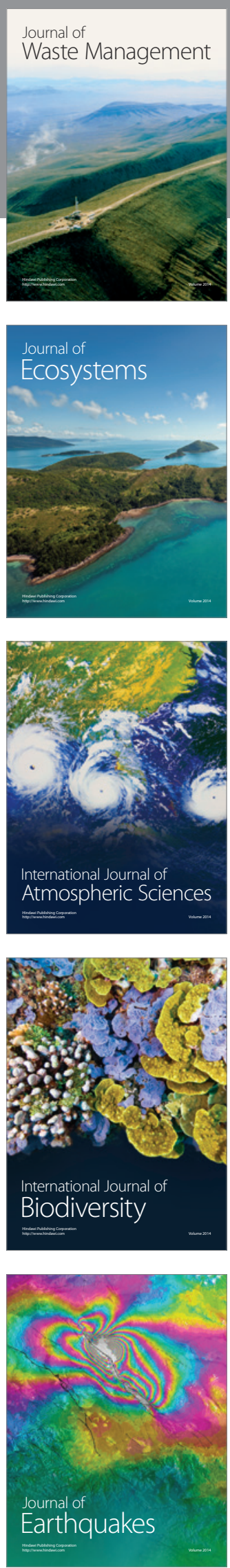
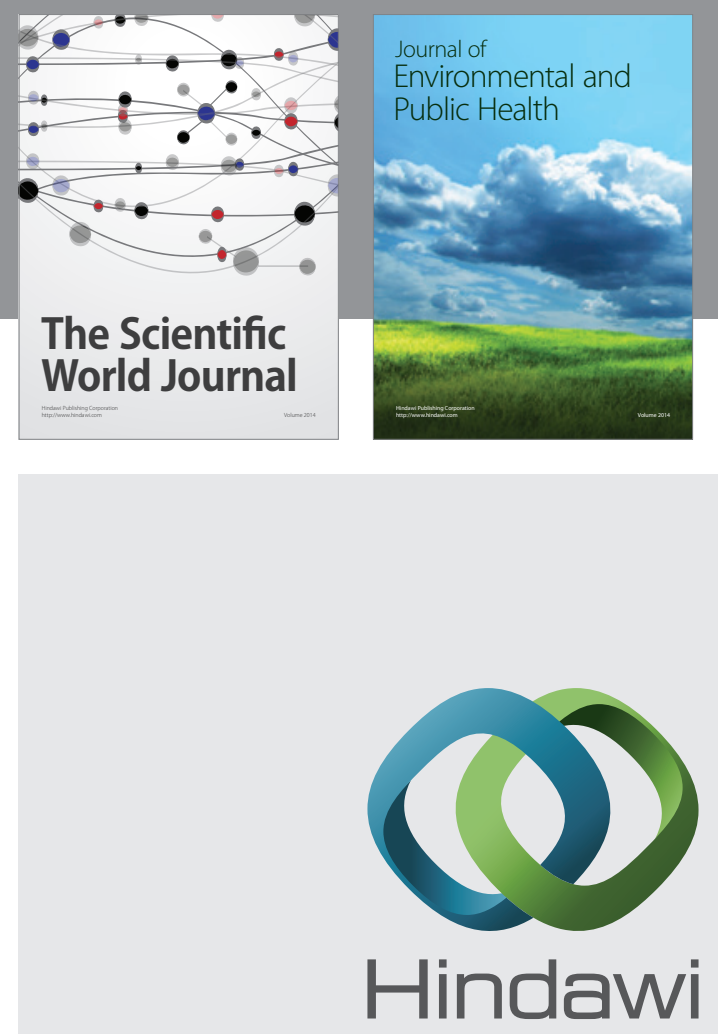

Submit your manuscripts at

http://www.hindawi.com
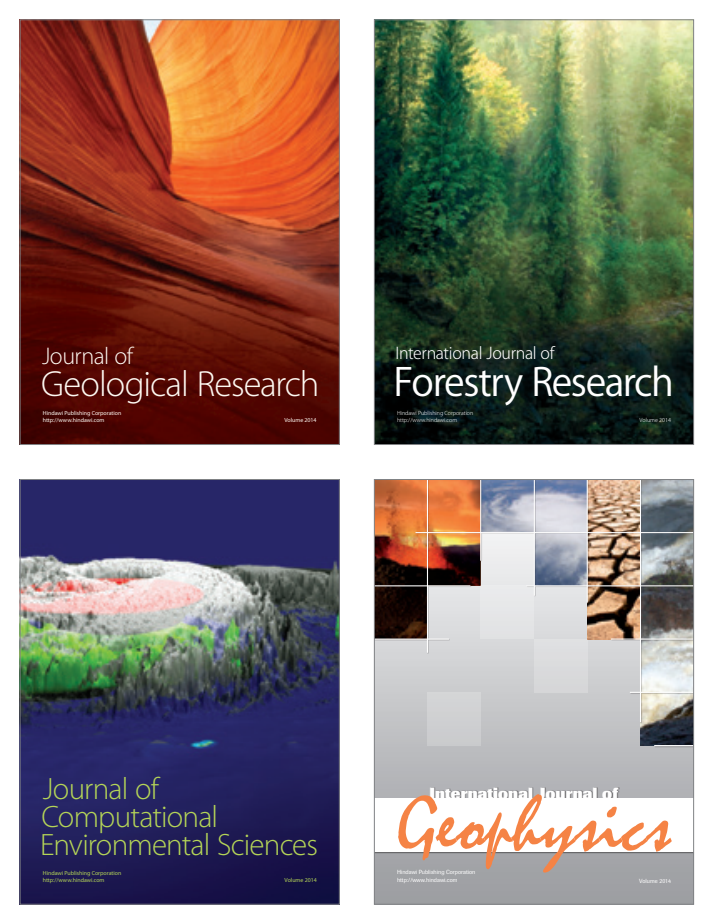
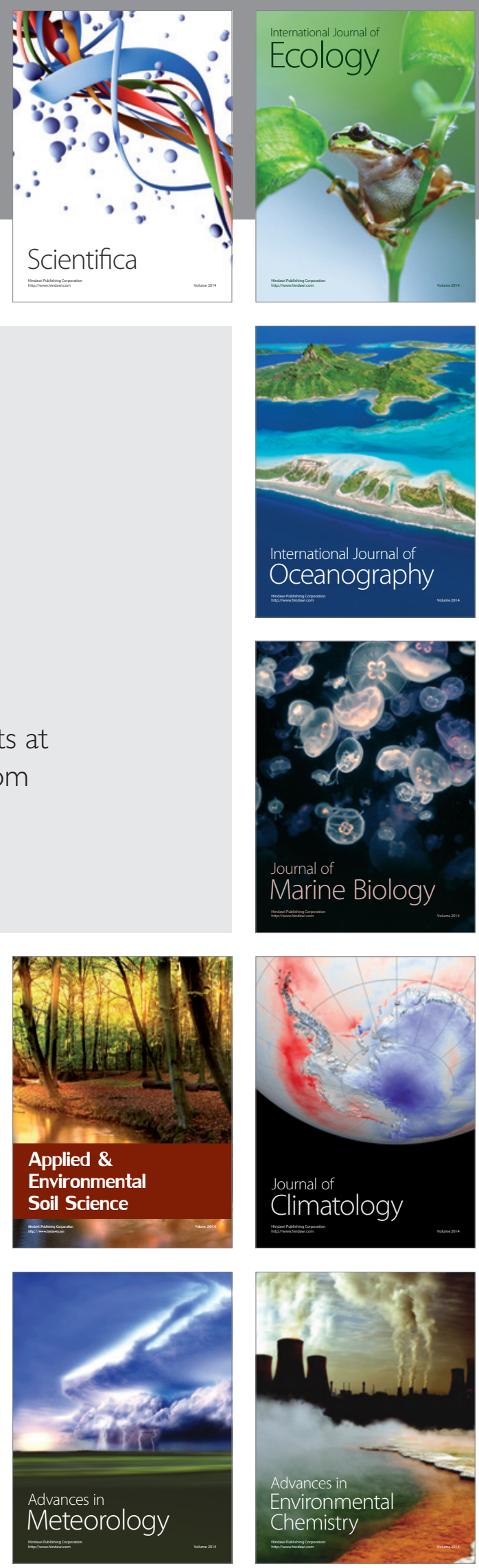